\title{
The Label of a City as an Element of the Knowledge Economy: The Case of the "City of Science", Darmstadt
}

DOI: 10.19181/inter.2019.19.5

\section{Iuliia Eremenko*}

Many cities all around the world have an official label of or call themselves "City of Science". Marketing studies have shown the influence of this label on the level of attractiveness of this territory for national and international investors. However, these studies do not explain the reasons for the desire to acquire such a label if the city has the opportunity to qualify for a label associated with the tourism industry. The article considers a city's image as a construction created in the conditions of competition between cities in the financial market and shows what resources are used by urban marketing to create an image of an ideal place for scientific activity. In this article, we look into the example of the German "City of Science" - Darmstadt. The study is based on a series of semi-structured interviews with experts in urban history and city development: representatives of scientific organizations, local politicians, urban activists and supervisors involved in the adaptation of students. Furthermore, a qualitative analysis of the contents of booklets and brochures which describe the city and are produced by the local administration was used. Based on this material, Darmstadt's representations as a "City of Science" in marketing publications and Darmstadt's citizens' daily perception are analyzed. The result of the study was a statement of the unequal representation of Darmstadt's image for an external consumer, based on the "City of Science" label, and the material space and Darmstadt's perception by its inhabitants, for whom social interaction on a district and scientific organization level is the decisive factor for labelling the city.

Keywords: label; City of Science; local communities; case-study; knowledge economy; Germany

\section{Introduction}

Nowadays, a unique urban culture is used for profit. Not only is the culture of the past sold, but also the architectural and historical heritage created by previous generations, but also the culture that is produced here and now. This is

* Eremenko luliia - Junior Researcher at SI RAS - FCTAS RAS; PhD Student at Saint-Petersburg State University and University of Bamberg (Germany), eremenko.iuliia@gmail.com. 
called the creative industries, which are, on the one hand, art, and on the other, science and high technology (Florida 2002). Developing modern technology and attracting scientific staff becomes an essential task for cities in the era of deindustrialization, since scientific activities today can be a primary economic source. Cities used to be a center of industry and, therefore, were economically successful. Then they became centers of service, which allowed them to remain commercially successful. However, this is no longer enough, as industry has moved away from cities to the periphery or to countries where it is cheaper to produce products. In its turn, the service sector no longer satisfies public demand. At this point, a knowledge economy emerges, which extracts the primary resources from the production of non-material content: ideas, technologies, etc. (e.g. Powell, Snellman, 2004; Brinkley, 2006; Lüthi, Thierstein, Bentlage, 2013). In this regard, it becomes clear why the concentration of scientists and technologies in cities becomes such an important task, as they are resources for this new knowledge economy. At the same time, it is not clear why several cities need the official label of "City of Science" (in the future CSL). Is this label just a form of stating the fact that this city is developing in the logic of the knowledge economy, or this status a unique tool that provides specific reputation resources? If it is a tool, what audiences is it intended for? While it can be assumed that this is one of the tools to attract tourists, thus a kind of symbolic capital, which is converted into economic capital at the expense of the tourism industry, this tool allows for attracting even more scientists. Therefore, this status is an official confirmation that the city is conditionally "scholarly friendly" with a broad base for scientific contacts and the necessary equipment.

This article will attempt to answer these questions. This research will look at the intended audience of the CSL and for what reasons the CSL is used by various actors. For the present study, the case of Darmstadt city was chosen. Darmstadt is a part of the Rhine-Main-Neckar metropolitan area, close to Frankfurt, one of the largest administrative, political, and economic centers of Germany; nevertheless, the city has preserved strong urban identity. The materials for the study are semi-structured interviews with experts in the field.

Further in the article, the main theoretical approaches to the analysis of the impact of the special status of cities on the cities will be analyzed. Then, empirical analyses will be employed to find the main actors influencing the label, with a final look at the influence of the label on attracting tourists and researchers.

Although place marketing has been taking place since colonial times, when governments attempted to convince people to move to newly conquered territories (Gold, 1994). The local city-forming industry model of the 19th century has died, and with it, urban settlements also fell into decay. Global business is no longer tied to a specific place (Bauman, 1998), and therefore easily removes all social responsibility. Nowadays, the restructuring of industrial cities into post-industrial ones has forced cities to implement ambitious reimaging strategies to appeal to a variety of external audiences: investors, immigrants and tourists etc. (e.g. Ashworth, Voogd 1990; Avraham, 2002; Holcomb, 1994). 
Many cities around the world are attempting to acquire a distinctive "face of the city" (Andereck, Nyaupane, 2011; Lindner, 2010: 44-45), to construct its identity and the structures of its logic (Löw, 2010: 13-14). Many previous studies are devoted to the influence of the tourist brand on the city (e.g. Andereck, Nyaupane, 2011; Gursoy, Chi, Dyer, 2010). Many of them have conceptualized residents' attitudes towards tourism by measuring their attitudes to the impacts of the industry (e.g. Andereck, Vogt 2000; Huh, Vogt 2008). Proponents argue that tourism is a labor intensive sector that carries a low capital cost of job creation, spurs economic development, improves a city's built environment, and enhances leisure provision for residents (Shaw, Williams, 1994).

\section{Materials and Methods}

The choice of Darmstadt as an example of the effect of the "City of science" status is not accidental. When choosing the object of study, three crucial characteristics were taken into account. The first, as noted earlier, is that despite being close to an important economic center such as Frankfurt, Darmstadt has retained its strong local identity. Another vital feature that influenced the choice of this case is that this city received the status officially from the administration of its territorial union (land), thus, this is not an informal self-designation, as in the cases of other cities. Also, Darmstadt is a medium-sized city in Germany, and the policy implemented in it does not change depending on the area of the town, as happens in large cities.

Empirically, this study uses a qualitative approach as it is concerned with producing detailed descriptions of particular phenomena. A guide was developed for the semi-structured interviews with experts in the field. The study is based on a series of semi-structured interviews with experts in urban history, city development and placemaking from Darmstadt: (1) representatives of scientific organizations, (2) local politicians (3) urban activists, (4) supervisors involved in the adaptation of students. The interviews were collected in 2016 and 2019 and the total number of collected interviews amounts to 15. In addition, a qualitative analysis of the content of booklets and brochures describing the city produced by the local administration in the period from 2016 to 2019 was carried out.

Semi-structured interviews with experts were divided into three blocks and lasted from 40 minutes to 2 hours. The first block was common to all the experts and included questions about how long a person lives in Darmstadt, how this city differs from others and what they know about the label "City of Science", its influence and significance. The second block was devoted to the urban economy and the place of tourism in it. The third block was individual for each expert group and concerned their professional field.

After reviewing the existing literature and conducting interviews, some preliminary open coding was done to "make comparisons of the data to concepts 
derived from the literature" (Strauss, Corbin, 1998: 49). The purpose of the open coding was to explore how to conceptualize the details of the data, which consisted of breaking down sentences and fragments into thematic categories. Axial coding also included the continued development of properties and dimensions for the developing categories started in open coding.

A qualitative analysis of the booklets commissioned and distributed by the city administration was also carried out. It considered how the city is described in the tourist booklets and booklets on the city's infrastructure. This material was necessary to understand the extent to which the label is actually broadcast by the city administration and how the city administration positions the city. The analysis focused on identifying differences in the positioning of the city in tourism booklets and booklets for long-term visitors, such as working or studying in Darmstadt. The frequency of mentions of CSL was evaluated, including the absence of mentions. Furthermore, arguments were analyzed in relation to the mentions of CSL, including any statistical data given. A special category of booklets are those produced by the host organization, most often the Darmstadt Technical University, for visitors to conferences and other scientific events. These materials often duplicate information from Wikipedia and do not differ among themselves in their description of the city.

\section{Actors of Urban Identity Making}

What does it mean to be a "City of Science"? This label means that a city has outstanding prospects for research and science on the national and the international level. In a "City of Science", science is a high-quality economic factor. With its high proportion of employees in sectors of research and science on the job market, such a city adopts a country-wide leading position. This official label (German: Wissenschaftsstadt), which was lent to Darmstadt in 1997 with a certificate by the Hessian Ministry of the Interior, recognizes the value of the city in the areas of science and research. For example, in 2009 the city of Darmstadt had by far the highest share of added value of using cutting-edge technology in knowledge-intensive services $(12,7 \%)$. This was followed by the Main-Taunus district with a share of 7.2\% (Donhauser.., 2011: 279-280). Here, as well as in the city of Darmstadt, this can be led back to the economic sector "data processing and databases" (ibid).

Large science and electronics (later information technology) sectors, as well as industry (especially chemicals) became increasingly important, and are still a major part of the city's economy (Hessisches Statistisches.., 2017; Hessisches Statistisches.., 2019b). The chemical element "Darmstadtium" (atomic number 110) in Darmstadt (GSI Centre for Heavy Ion Research) was discovered (International Union.., 2003).

There are different actors who have effects on a CSL. To designate them all does not seem possible, and the actors are strongly associated with 
the specifics of the city. There are several important actors that contribute to this CSL formation in Darmstadt. They differ in access to resources (political, economic, information). The actors distinguished in this case-study of Darmstadt include, first of all, the city administration, educational institutions (universities, technology colleges), and local companies. As a component of Darmstadt's urban identity, the information component of the CSL like a branding strategy is strong, which is supported by city administration, scientific organization like universities and research centers, local companies, student clubs and communities.

The city administration uses almost all available resources (legal and political, economic-budgetary, informational) and consists of a municipal council elected (according to the constitution of the federal state of Hesse) by members of the city assembly of deputies (Stadtverordnetenversammlung), and also from the mayor's office, under the leadership of the mayor (Oberbürgermeister), elected by the citizens of Darmstadt. The key elements of working with the CSL in the case of the administration are decision-making and the implementation of urban adaptation programs for "newcomers" (workers, students and etc.).

Universities and scientific institutes are an important part of urban identity making and have an influence on the CSL.

"It's a very small town in comparison, and I think institutions of education, yes, that's a big part of Darmstadt, because it's a big area where students come to study and it's a huge community" (Administration 2).

The city owes its title of "City of Science" to its University of Technology (founded in 1877), Darmstadt University of Applied Sciences (founded in 1971), Evangelische Hochschule Darmstadt (founded in 1971) and 30 research institutions. 45 thousand students study at the city's universities, which is about a third of all residents. It is very easy to conclude that the decisions taken by the Darmstadt University of Technology (TU) are very important (See, for example, Top Germany University). Universities are not state-owned and have their own budget and it is important for them to attract students.

Another important actor are local companies. The activity of many large organizations is associated with high-tech production, which requires the participation of highly qualified specialists. Successful graduates can immediately get a job after graduation in a company located here in Darmstadt:

"It is advantageous for companies to open offices in Darmstadt as students can take internships with us while they are still studying at the University" (Business 1).

In addition, there are student clubs and communities in Darmstadt that do not belong to any University. These clubs bring together students and scientists from different organizations within the city: 
"And we are partners for the TU and for the other universities located in Darmstadt. And we work with them. Together with them. We also have cooperation with different parts of the university. For example in the Institute Darmstadt" (Supervisor 1).

They also organize their own events for the students of all the educational institutions of the city. These activities are aimed at improving communication between the representatives of different countries and to explore the city. They are funded through the universities' partners and various grants.

\section{"City of Science" as a touristic label}

At the end of the 20th century, a new type of consumer emerged in the worId, the "global tourist" who travels the world in groups or alone, fills the centers of historic cities and becomes part of the city itself (Ptichnikova, 2010). Tourists become another group in the urban environment influenced by the label. Depending on the label, tourists, even if they do not come to the city, are shaped by their expectations and the kind of leisure they may find.

For attracting tourists, Darmstadt has something to show, even though the city was severely damaged during the Second World War. The destruction is one of the reasons why nowadays, Darmstadt is one of the centers of modern architecture (Photo 1). Not only are the buildings of scientific centers and higher educational institutions of architectural value, but also residential buildings. Despite this, the buildings not destroyed in the Second World War are preserved by the city administration:

"The city administration, I think, carefully maintain the order in the city, it supports and takes care of objects that were erected after the Second World War. There is a number of high-quality restoration work there. This work is visible for everyone in the city" (Politician 1).

However, the purpose of this restoration is not to attract tourists, but to create recreation areas, aesthetically pleasing to the locals. One of these is the area around the Orthodox Church, which is positioned in the brochures of the city administration not as a religious building, but as an area with fountains and gazebos, where you can spend time in view of a beautiful architectural structure.

Analyses show that not all residents want their city to be popular among tourists. Tourism has a negative impact on traditional employment patterns (Haralambopoulous, Pizam, 1996). As a result, residents often oppose tourism as an economic development strategy. This is confirmed by a number of other studies (e.g. Petrzelka et al., 2006; Smith, Krannich, 1998).

Despite the fact that Darmstadt is not trying to attract tourists on a regular basis, the city has special events, often referred to as "hallmark events", to improve place image (Nielsen, 2001). The main "hallmark events" are related to the scientific sphere: conferences, forums, etc. However, it is not true that tourists do not 


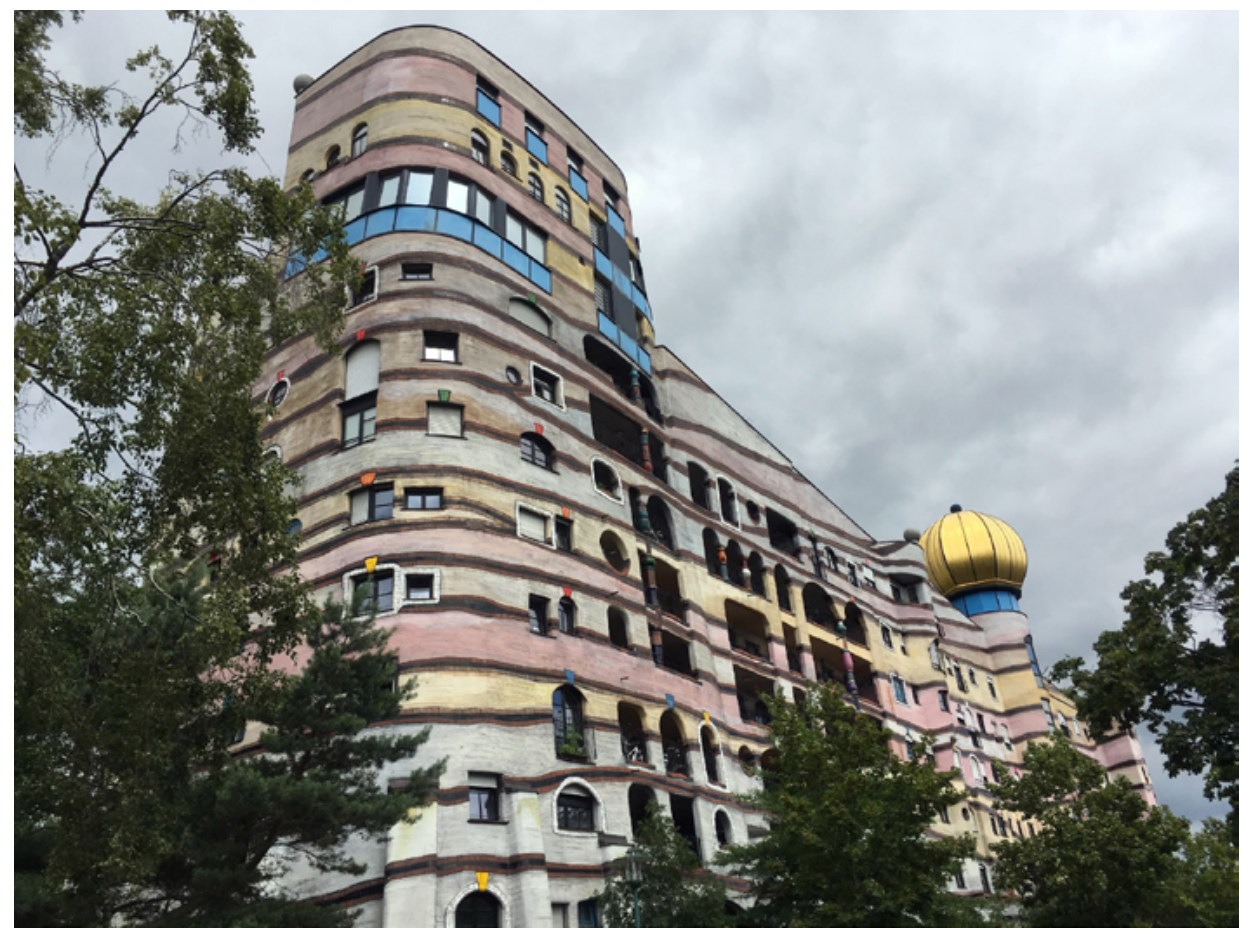

Photo 1. Residential complex by Austrian Friedensreich Hundertwasser "Waldspirale" ("Forest Spiral"). Source: Iuliia Eremenko.

come to the city and that there are no entertainment activities that would be interesting for tourists.

The image of the city of science is connected to the fact that it is opposed to noisy cities filled with tourists:

"If you want to work in peace, you need to be able to rest in peace. Darmstadt is a really good place for it" (Member of Scientific organization 1).

"There are no crowds of tourists. No one bothers you to walk around the city and enjoy the silence" (Politician 4).

Tourists are seen here as something that brings noise and changes the quiet life of the city:

"No one wants foreign tourists yelling at their windows" (Urban activist 3).

Usually experts oppose tourist flows in Frankfurt and Darmstadt:

"Darmstadt and Frankfurt are really different. Because Frankfurt is such a financial area. A lot of tourists, and people in general, in Darmstadt it is much quieter and safer" (Member of Scientific organization 2). 
The city administration produces brochures and booklets that can be divided into two categories: (1) for visitors of the city and (2) for investors and future residents. Best of all, the first category describes the name of the main city tour developed by the city administration - "Darmstadt at a glance". The tourist attractions of Darmstadt, as shown by this tour, can be viewed in a few hours. The underlying message of booklets and the tourist page of the city portal are made on modern technologies, so it is possible to see the city center thanks to a particular program from home and to receive a portable charger from the tourist center, which is useful, because a description of all the attractions can be found in a particular application for mobile phones.

There are different entertainment events in Darmstadt. They are attended not only by citizens but also by participants from all over Germany. The major city event is called Heinerfest (Photo 2). The name of the event refers to how the residents of the city call themselves:

"I know some city residents who call themselves Heiners. This is because they have Heinerfest festival. Residents of Darmstadt in their everyday lives name themselves Heiners" (Urban activist 1).

This is a way of self-identification of citizens, their desire to show their connection with the city.

In general, the CSL prioritizes visitors from the scientific community over tourists, i.e. people who come to scientific conferences and other events with a high rating organized by institutions and companies. Such visitors are perceived positively in the city, as they are considered as those who contribute to the development of science and the city as a whole:

"Scientists and specialists who come bring new ideas that can be developed in the future in our institute too" (Member of Scientific organization 2).

The city administration believes that this label makes tourists understand that in Darmstadt they are not the main actors:

"If you look where to go for the weekend, seeing our label you will think that Darmstadt is a boring place and maybe you prefer some other places to visit. However, if you are scientists, you will probably be interested to know what institutions and companies we have in Darmstadt" (Politician 4).

Locals react differently to the emergence of "global tourists" on their streets. Some see them as a means for the economic development of the city, while others see them as a hindrance. In the case of Darmstadt, the CSL is a protective mechanism against "global tourists" who, according to residents, disrupt the measured urban life focused on the needs of researchers. 


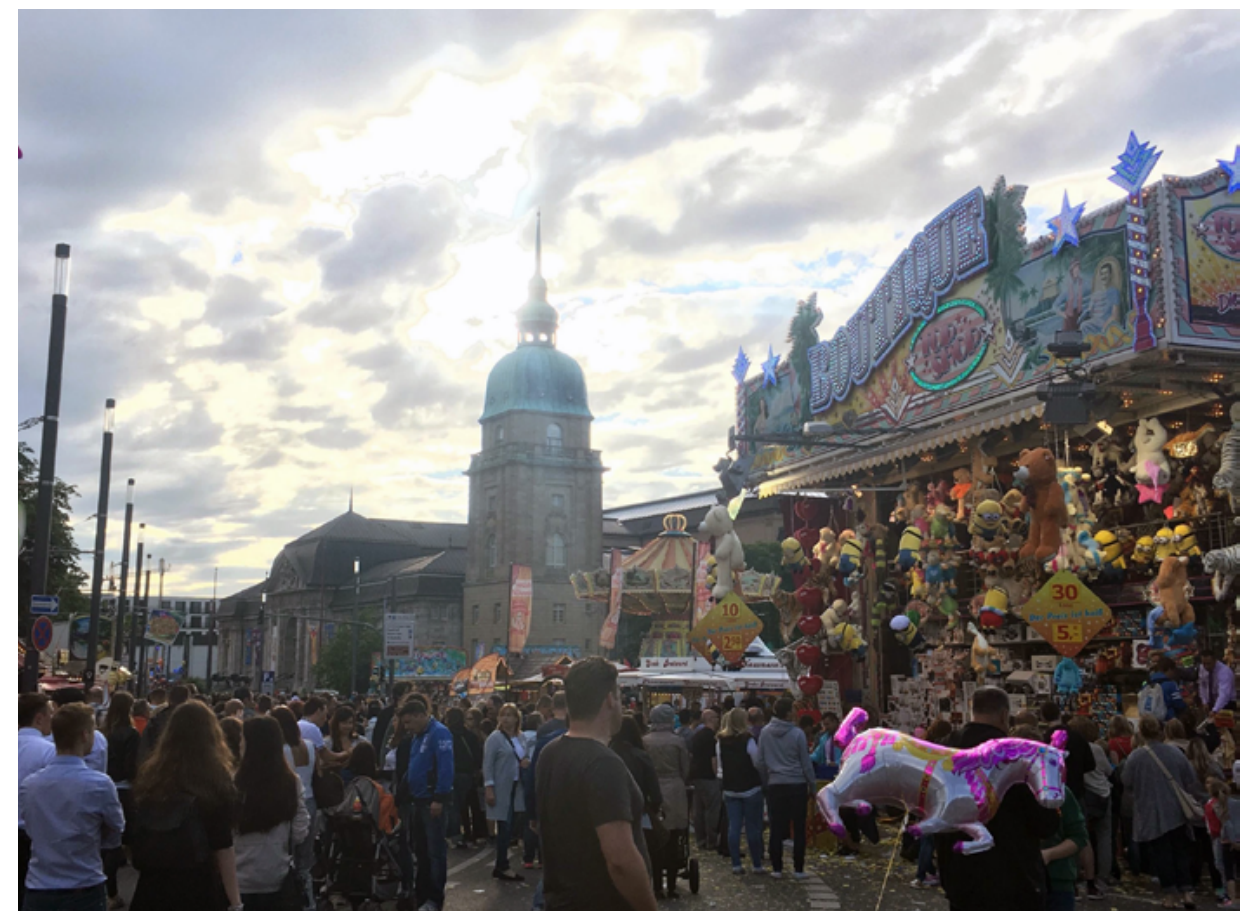

Photo 2. Heinerfest 2016. Darmstadt, Marion-Gräfin-Dönhoff-Platz. Source: Iuliia Eremenko.

\section{Scientists in the "City of Science": the image of a local resident}

Cities of science are based on three main principles: dynamism, innovation, and future orientation. This status does not merely imply the existence of universities, academies, and higher education institutions with a practical orientation, but has a lively scientific community and means a city full of creative and clever minds, and it wants to remain this way in the future. These goals are based on a study by the OECD, the Organization for Economic Cooperation and Development, which predicts that in ten years' time about $40 \%$ of all jobs will require scientific and technological training. One of the main differences from such cities as Oxford and Cambridge can be called the priority of innovation over tradition:

"Darmstadt has been badly damaged. The city was almost gone. However, this has given us the opportunity not to look back on tradition, as ancient cities do. We can implement new projects at once" (Urban activist 2).

The status of a city of science is an additional incentive to develop perceptions and stimulate dialogue between urban society and its scientists on how people want to live in the future. Promoting talented people, as well as technology and research, provide a decisive foundation for achieving this goal.

Darmstadt is positioned by city administration as a place for life and productive work for scientists: 
"Our citizens are mainly included in the world of science. If not directly, then thanks to their partners, neighbors, colleagues, etc." (Politician 1).

Also in describing the local population, the administration uses such terms as creative and intelligent both in interviews and in printed materials. Indeed, if you look at the study conducted by Fritsch and Stuetzer, the population of the city can be called creative (on the Photo 3 , the territory of Darmstadt is marked in red.).
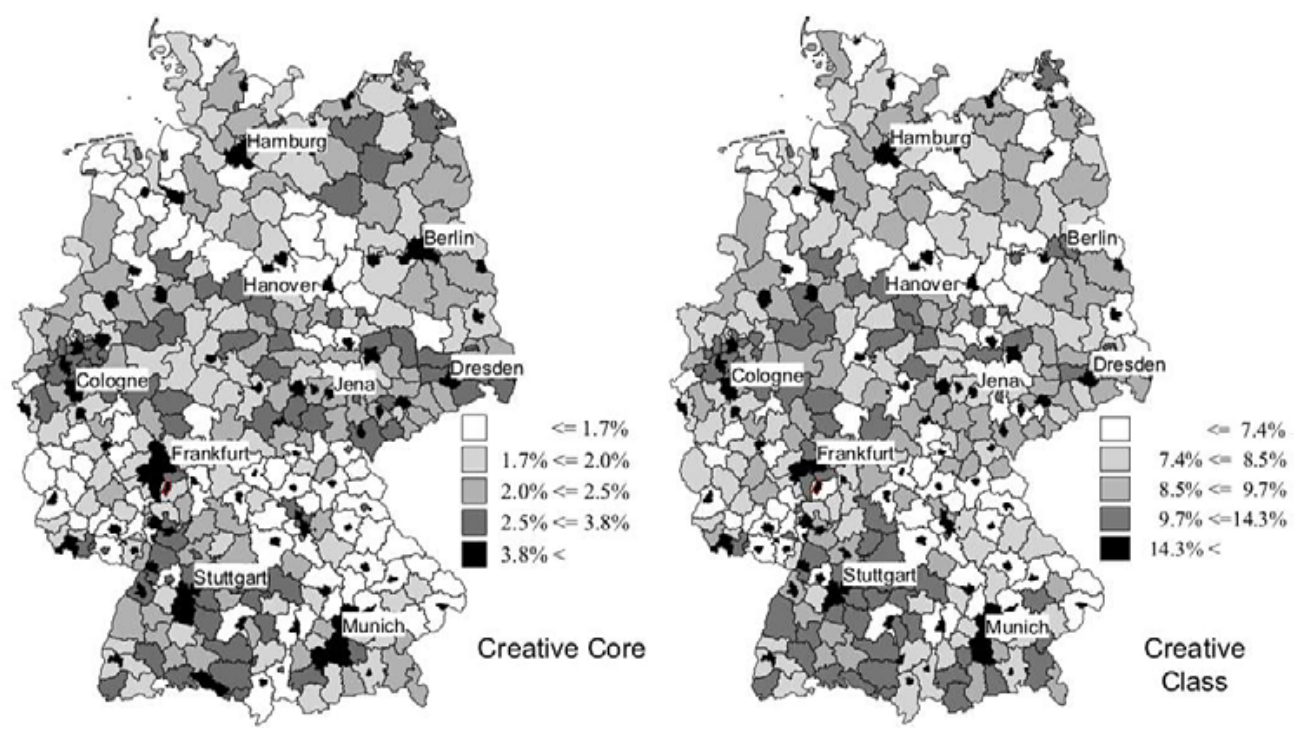

Photo 3. Population share of Creative Core and Creative Class in German districts 2004. Source: (Fritsch M., Stuetzer M., 2009).

One of the functions of the label in Darmstadt is to be an instrument of retention due to which the best professionals after graduation would have stayed here to live and work. Experts say that the city needs qualified workers. This is true not only in the science industry, but also for regular city life maintenance. There is a major educational center in Darmstadt.

"In these vocational schools are trained not only migrants but also urbanites. It unites them as a University to be included in the life of the city. This work is not considered prestigious. After graduation, they get good money. It helps the economic development of the town" (Politician 2).

The residents call Darmstadt "a small city" ("Eine kleine Grossstadt" (Urban activist 1)), as a place where there are all the advantages of a big city, such as supermarkets, cinemas, stadiums, but there are not so many people on the street as in large cities. The very close ties of the city with such a center of the country's political and economic life as Frankfurt has the most important influence on self-identity, because during the interviews almost everyone 
has made a comparison of Darmstadt to Frankfurt. For example, in discussing the aesthetic aspect of the city, one expert makes an explicit comparison with Frankfurt:

"I think that in big cities like Frankfurt there are many new skyscrapers. Probably, these buildings in the city center change the perception of the city and the city's identity. The central part is not an ancient one and it is getting more modern these days. Maybe it should happen this way, but from the point of view of the old city center, the city and space are changing dramatically. Because there are not so many big buildings" (Supervisor 1).

The CSL is an indicator showing that this city is for those who are engaged in science. The administration uses data on the number of immigrants as an argument. The leading case is that the city already has many immigrants, and their number is growing, so the international level of the scientific community is growing in turn. The city administration broadcasts through the official website the image of a tolerant city: "Since 1998, the city of science has been a city of immigrants. On 31 December 2014 the population of Darmstadt was 154,002 inhabitants and rising". (Wissenschaftsstadt Darmstadt, 2017). Today, there are almost 160,000 inhabitants. (Hessisches Statistisches.., 2019a). The city administration considers it essential to emphasize through this label that the city already has a formed scientific community and that new people, if they are from the world of science, will find it easier to integrate into an intercultural community consisting not only of Germans but also of representatives of other countries:

"We show by this status in a brief form that it is an international scientific center" (Politician 2).

"We have many foreigners. The status of the city of science unites us all" (Supervisor 2).

The possibility of learning from other members of the city community plays an important part in Darmstadt as a City of Science:

"We are constantly learning here. At work, on courses, even on the bus, you can learn something new" (Urban activist 3 ).

Supposedly, this may have a similar rationale to the label's influence on participation in local communities. A number of scientists have also found that such a concentration around a particular label is associated with major motivations to interact with a community, whose members participate in the exchange of knowledge (Fournier et al., 2001; Dholakia, Bagozzi, Pearo, 2004). In the future, this aspect requires a separate, more detailed study. 


\section{Conclusions}

The label of "Cities of Science" is a brief description of a city's development strategy. Urban planning is aimed at the development of the knowledge economy and attracting tourists is not a priority for the local administration in this case. The CSL is not just a statement of the fact that there is a large number of people associated with the scientific industry. Darmstadt has a really large percentage of the population employed in the so-called creative professions, which is one of the factors in the formation of the so-called creative economy. However, this label is a tool that is used to solve certain problems.

The CSL is considered by the city administration, scientific institutions and representatives of local business as a reputation resource. It is not a form of tourist attraction, like other statuses possessed by other cities in Germany, such as World Heritage Cities. Rather, such key actors as the staff of the scientific institutes perceive tourists in a negative way, something that interferes with their daily lives. Perceiving this attitude to tourists, the city administration does not develop a tourist destination, forming the main focus of its activities to create a favorable environment for those who live in the city.

This reputation resource allows you to attract more researchers. The city receives a kind of confirmation that in its territory, scientific activity is considered as the main professional activity, and urban planning is developed with this in mind. Local politicians are aware of the lack of highly qualified personnel and try to create conditions that in the logic of the neoliberal economy will bring them the most significant benefit. In this case, it is the creation of an infrastructure convenient for residents employed in the scientific sphere, followed by large companies and financial investments into the city.

\section{References}

Andereck K. L., Nyaupane G.P. (2011) Exploring the nature of tourism and quality of life perceptions among residents. Journal of Travel Research. No 50. P. 248-260.

Andereck K. L., Vogt C.A. (2000) The relationship between residents' attitudes toward tourism and tourism development options. Journal of Travel Research. No 39. P. 27-36.

Ashworth G. J., Voogd H. (1990) Selling the City. Belhaven Press, London.

Avraham E. (2002) Cities and their news media images. Cities. No 17. P. 363-370.

Bauman Z. (1998) Globalization: The human consequences. Columbia University Press.

Brinkley I. (2006) Defining the knowledge economy. London: The work foundation.

Dholakia U. M., Bagozzi R.P., Pearo L. K. (2004) A social influence model of consumer participation in network-and small-group-based virtual communities. International journal of research in marketing. No 21 (3). P. 241-263.

Donhauser S. (2011) Wirtschaftsleistung und -strukturen sowie Einkommensverteilung und -umverteilung in den Verwaltungsbezirken Hessens. Staat und Wirtschaft in Hessen 10/11.

Florida R. (2002) The rise of the creative class. NY: Basic books.

Fournier S., Sensiper S., McAlexander J.H., Shouten J.W. (2001) Building Brand Community on the Harley-Davidson Posse Ride. Harvard Business School Case, Reprint 501009, Boston. 
Fritsch M., Stuetzer M. (2009) The geography of creative people in Germany. The International Journal of Foresight and Innovation Policy. No 5 (1-3). P. 7-23.

Gold J.R. (1994) Locating the message: place promotion as image communication / In: J. R. Gold, S.V. Ward (eds.) Place Promotion: The Use of Publicity and Marketing to Sell Towns and Regions. Chichester, UK: John Wiley \& Sons.

Gursoy D., Chi C. G., Dyer P. (2010) Local's attitudes toward mass and alternative tourism: The case of Sunshine Coast, Australia. Journal of Travel Research. No 49 (3). P. 381-394.

Haralambopoulous N., Pizam A. (1996) Perceived impacts of tourism: The case of Samos. Annals of Tourism Research. No 23 (3). P. 503-526.

Hessisches Statistisches Landesamt (2017) Erwerbstätige (am Arbeitsort) in Hessen 2017 nach Verwaltungsbezirken 2017.

Hessisches Statistisches Landesamt (2019a) Die Bevölkerung in den hessischen Gemeinden am 31.03.2019 (Ergebnisse auf Basis Zensus 2011).

Hessisches Statistisches Landesamt (2019b) Erwerbstätige (am Arbeitsort) in Hessen nach Wirtschaftsbereichen 2019.

Holcomb B. (1994) City make-over: marketing the post-industrial city / In: J. R. Gold, S. V. Ward (eds.) Place Promotion: The Use of Publicity and Marketing to Sell Towns and Regions. Chichester, UK: John Wiley \& Sons, P. 115-131.

Huh C., Vogt C. A. (2008) Changes in residents' attitudes toward tourism overtime: A cohort analytical approach. Journal of Travel Research. No 46. P. 446-455.

International Union Of Pure And Applied Chemistry (2003) Element 110 Is Named Darmstadtium. ScienceDaily. // URL: www.sciencedaily.com/releases/ 2003/08/030820073330.htm (accessed 19 August 2019).

Lindberg K., Johnson R.L. (1997) Modeling residents attitudes toward tourism. Annals of Tourism Research. No 24 (2). P. 402-424.

Lindner R. (2010) Maß und Mitte. Middletown revisited. In: Schmitt-Lauber B. (Hg.) Mittelstadt. Urbanes Leben jenseits der Methropole. Frankfurt am Main: Campus Verlag, P. 37-52.

Löw M. (2010) Soziologie der Stadt. Frankfurt am Main: Suhrkamp.

Lüthi S., Thierstein A., Bentlage M. (2013) The relational geography of the knowledge economy in Germany: on functional urban hierarchies and localised value chain systems. Urban Studies. No 50 (2). P. 276-293.

Nielsen C. (2001) Tourism and the Media. Hospitality Press, Melbourne.

Petrzelka P., Krannich R. S., Brehm J., Trentelman C. K. (2005) Rural tourism and gendered nuances. Annals of Tourism Research. No 32 (4). P. 121-1137.

Powell W.W., Snellman K. (2004) The knowledge economy. Annual Review of Sociology. No 30. P. 199-220.

Ptichnikova G.A. (2010) Arhitektura i potrebitel: metamorfozyi goroda pod vliyaniem globalnogo turizma. Sotsiologiya goroda. No 3. P. 10-15. (In Russ.)

Shaw R., Wong Y. (1989) Genetic seeds of warfare: evolution, nationalism and patriotism. Boston: Unwin Hyman.

Sidhu R. (2009) The "brand name" research university goes global. Higher Education. No 57 (2). P. $125-140$.

Smith M., Krannich R. (1998) Tourism dependence and residents attitudes. Annals of Tourism Research. No 25 (4). P. 783-801.

Strauss A., Corbin J. (1998) Basics of qualitative research (2nd ed.). Thousand Oaks. CA: Sage.

Wissenschaftsstadt Darmstadt (2019) Leben in Darmstadt // URL: https://www.darmstadt.de/lebenin-darmstadt/ (accessed 19 August 2019). 


\section{Имидж города как элемент экономики знаний: кейс «города науки" Дармштадта}

DOI: 10.19181/inter.2019.19.5

\section{Юлия Еременко}

Еременко Юлия - младший научный сотрудник СИ РАН-филиала ФНИСЦ РАН; аспирантка Санкт-Петербургского государственного университета и Университета Бамберга (Германия), eremenko.iuliia@gmail.com.

Многие города по всему миру имеют официальный или неофициальный имидж «города науки» (наукограда). Маркетинговые исследования показывают, что наличие этого имиджа положительно влияет на уровень привлекательности территории для национальных и международных инвесторов. В статье рассматривается имидж города как конструкт, который формируется в условиях конкуренции между городами. На примере немецкого «города науки» Дармштадта показано, какие ресурсы используются городским маркетингом для создания имиджа идеального места для научной деятельности. Статья базируется на материалах авторского исследования, состоящего из серии полуструктурированных интервью со специалистами по истории и развитию города: представителями научных организаций, местными политиками, городскими активистами и руководителями, занимающимися адаптацией студентов. Кроме того, был проведен текстовый анализ содержания буклетов и брошюр о Дармштадте, которые выпускаются местной администрацией. На основе этих материалов анализируются репрезентации Дармштадта и его имиджа «города науки» как в маркетинговых публикациях, так и в повседневном восприятии местных жителей. Автор приходит к выводу о различиях в репрезентациях Дармштадта, основанных на бренде «города науки» и направленных на внешнего потребителя, и физического пространства города, а также восприятия Дармштадта его жителями, для которых повседневные взаимодействия и уровень научных организаций являются ключевыми элементами имиджа города.

Ключевые слова: бренд территории; город науки; местные сообщества; кейсстади; экономика знаний; Германия 